Article

\title{
Evaluation of an Educational Model Based on the Development of Sustainable Competencies in Basic Teacher Training in Spain
}

\author{
Pedro Vega-Marcote ${ }^{1, *}$, Mercedes Varela-Losada ${ }^{2}$ and Pedro Álvarez-Suárez ${ }^{3}$ \\ 1 Faculty of Educational Sciences, University of Coruña, A Coruña 15071, Spain \\ 2 Faculty of Educational Sciences, University of Vigo, Vigo 36005, Spain; \\ E-Mail: mercedesvarela@uvigo.es \\ 3 Faculty of Educational Sciences, University of Granada, Granada 18002, Spain; \\ E-Mail: palvarez@ugr.es \\ * Author to whom correspondence should be addressed; E-Mail: pedro@udc.es; \\ Tel.: +34-981-167-100 (ext. 14633).
}

Academic Editor: Ian Thomas

Received: 12 December 2014 / Accepted: 25 February 2015 / Published: 3 March 2015

\begin{abstract}
The environmental deterioration of the planet, caused by unsustainable development and an unfair model, requires global change on a political, social and environmental level. To boost this change, it is necessary to redirect education and, specifically, environmental education, to educate citizens so that they are capable of making responsible decisions and behaving sustainably. The purpose of this study is to evaluate an educational teacher training model based on the development of sustainable competencies and on the solving of environmental problems. Its final aim is to search for a model that enables students to participate, individually and collectively, in the solution of socio-environmental problems in their surroundings, but without losing the global perspective, and that fosters sustainable life styles. To do so, a quasi-experimental quantitative research was performed with two pretest-posttest phases to compare the results of an active and participative methodology with another more expository one. The results show significant differences in the knowledge, attitudes and intention of the behavior of the aspiring teachers. Thus, this first analysis shows that the experiential educational model promotes and favors sustainable actions in higher education (the faculty of educational science, responsible for basic teacher training) more efficiently and could be the basis for future proposals in this field.
\end{abstract}


Keywords: educational model; sustainable competencies; environmental education; teacher training

\section{Introduction}

There is no doubt that rapid environmental deterioration is currently taking place, unprecedented on a global and regional level, which affects the more disadvantaged populations to a greater extent. The origin of these changes is in human activities that are increasingly immersed in a globalized, industrialized, consumerized and interconnected world, as has been acknowledged in recent reports [1-4] and specifically with regard to the social and environmental impact produced by climate change in the IPCC report [5].

Consequently, it is necessary and urgent to make decisions in this respect, to reduce the global use of energy and materials, as well as the generation of waste. This is not merely an option; it is a necessity demanded by a planet with limited resources. However, those who can decrease are, obviously, those who use up the resources in a major way and generate the waste, that is the richer countries [6]. The dominant socioeconomic models and the human activities they entail must not overload the vital functions nor deteriorate our world's environmental quality; its limits must be respected, and we must think about the future generations. It is urgent to find political, financial, social and environmental solutions that save the world from the edge of the abyss on which it is teetering $[7,8]$.

Therefore, in an attempt to put a stop to this deterioration, the need for sustainable development (henceforth SD) was proposed and defined as a way of meeting the needs of the present generation without compromising the ability of future generations to meet their own needs [9]. At the turn of the century, the United Nations set forth the Millennium Development Goals and even went a step further by pointing out that development must be socially fair, financially feasible and must not exceed environmental limits; indicating, also, that SD must be global, in order to prevent certain parts of the planet from growing at the expense of others, and all-inclusive, integrating the cultural and political spheres [10].

Specifically, with regard to education, the UN proclaimed the Decade of Education for Sustainable Development (2005-2014) [11] as "an invitation to rethink our educational policies, our programs and our teaching practices so that education can play its part in the preparation of the skills of all members of society to work together to build a durable future", because the increase of social sensitivity towards the defense of the environment that has been valued by citizens for decades has not translated into specific sustainable behavior $[12,13]$.

It is believed that the relationship between education and sustainable development is essential [14], for it is the predominant education systems that determine the type of society and individuals that prevail and, therefore, the degree, form and, above all, the development that is sought. The objectives and the methods used are determined by the ideology on which they are based. This is why it is essential to define the educational model that is required in order to achieve SD [15], in order to educate citizens to be capable of making environmentally-responsible decisions, of behaving sustainably and participating in the decision-making processes. This requires that citizens are not only 
aware of the challenges with which we are faced [16,17], but also, that they learn to analyze present-day and future problems and that they actively search for possible solutions [18]. Education, and, specifically, environmental education, directed towards SD plays a fundamental role in a global way; at all levels, therefore, this field requires adequate teacher training.

\subsection{Sustainable Competencies and Teacher Training}

To respond to the demands of today's society, the European Union is promoting a new educational model linked to the development of competencies, in our case focused on university-level teacher training $[19,20]$. These competencies are seen as the ability to respond to complex demands and adequately carry out a variety of tasks, combining practical skills, knowledge, motivation, ethical values, attitudes, emotions and other social components and behaviors that come together to achieve efficient action [21]. This movement, a feature of the competencies, implies the importance of developing activities linked to reality, the need for social interaction and the challenging of models based exclusively on the transmission of knowledge [22]. It is not enough to acquire concepts; it is necessary to learn to put them into action, integrate them and use them adequately under different real-life circumstances. Thus, competencies turn into learning achievements, instead of the mere acquisition of knowledge, fully affecting the teaching and learning process [23] and, particularly, the role of the teacher.

In the field of environmental education, many authors [17,24-27] also point out the need to focus environmental education on the development of sustainable competencies, based on a critical, active and participative view, which can lead us towards citizens who are informed, responsible and committed to the environment and people and who can act to solve today's and future problems.

From this viewpoint, sustainable competencies can be defined as complexes of knowledge, skills and attitudes that enable successful task performance and problem solving with respect to real-world sustainability problems, challenges and opportunities [27-29]. However, the integration of this new viewpoint is not exempt from difficulties [17,27,28,30]; it is necessary to clarify what these sustainable competencies are, to design educational proposals that contribute toward their development and to evaluate their achievement.

Therefore, we must search for educational models based on knowledge, where not only skills surface, but also, commitments and the willingness to act, through educational activities that allow us to:

(1) build a new model based on the principles of sustainability;

(2) understand the connection between the environmental, social, economic and cultural processes;

(3) be aware of the local and global (glocal) social and environmental problems and their relationships;

(4) train students to analyze socio-environmental conflicts during the debate, to find alternatives and in individual and collective decision-making;

(5) promote the extension of "sustainable best practices" in different contexts and cultures.

Thus, the development of sustainable practices should be part of a framework of research on sustainability and problem-solving [31,32], giving priority to the acquisition of environmental literacy based on critical thinking and contributing to the development of people who make knowledgeable 
decisions about their behavior, basically in relation to the main environmental problems [33], therefore relating critical thinking with an efficient use of decision-making skills [34].

Therefore, the design of educational proposals, in addition to favoring the profound understanding of the problem and the search for possible action strategies [35], should favor decision-making and the ability to act as per the sustainability criteria adopted [36]. This perspective implies that educational actions should seek the development of specific skills that foster sustainable actions based on sensible decisions for real-world and complex situations. The review of the literature on this subject [27] indicates five basic competencies that should be combined significantly and effectively to reach this aim:

- Systems thinking competence is the ability to collectively analyze complex systems across different domains (society, environment, economy, etc.) and across different scales (local to global), thereby considering cascading effects, inertia, feedback loops and other systemic features related to sustainability issues and sustainability problem-solving frameworks [37,38].

- Anticipatory competence is the ability to collectively analyze, evaluate and craft rich "pictures" of the future related to sustainability issues and sustainability problem-solving frameworks [39,40].

- Normative competence is the ability to collectively map, specify, apply, reconcile and negotiate sustainability values, principles, goals and targets $[41,42]$.

- Strategic competence is the ability to collectively design and implement interventions, transitions and transformative governance strategies toward sustainability $[39,42]$.

- Interpersonal competence is the ability to motivate, enable and facilitate collaborative and participatory sustainability research and problem-solving [37,39].

According to this focus, such competencies integrate the essential characteristics that promote the involvement of education with SD [43]: a holistic approach, envisioning change and achieving transformation.

In this new framework, teacher training is a basic pillar. If we want education to have a dual social function (to educate future generations through an integral model of sustainability (synchronic and diachronic support) and to contribute to changes in lifestyles), a reference framework for teacher training that backs up and specifies the educational proposals will be necessary $[15,30]$. The introduction of sustainable competencies in the curriculum implies a change in the teaching culture, which lays down the foundations to achieve the model of human beings and society that we want to establish [44].

Thus, the role of the university in the achievement of this target, as the figure responsible for the proper training of teachers, is quite significant, for it is faced with a profound review of its curricular activities, its management tasks and its research works [45]. In addition, it would have to develop a process to adapt to a world under constant change. Teacher training should become a means of information and communication for $\mathrm{SD}$, also making it possible to implement. However, several authors have denounced the scarce attention that education pays to preparing citizens to achieve a sustainable future [46]. The effect of university studies on student environmental literacy shows that it is normally very limited $[47,48]$. Consequently, most of the members of the university community are not trained in the principles that SD preaches, and therefore, they are neither aware nor prepared to act sustainably, that is to acquire sustainable competencies $[49,50]$. 
In summary, specific actions in teacher training that help promote sustainable lifestyles are required. Therefore, the purpose of this research is to evaluate how the application of an educational model based on the development of sustainable competencies produces an improvement in the knowledge, attitudes and intention of the pro-environmental behavior (directed at sustainability) of the aspiring teachers.

\subsection{Experimental Teaching Model}

This research evaluates an experimental educational model with a research-based nature and a socioecological approach [31], for the resolution (albeit not "the" solution) of socio-environmental problems (which are complex, global, local and systemic problems) from students' close environment (teachers in training). It is addressed from a participative and multi-disciplinary perspective, and its final aim is to contribute to the ability to act on these problems following sustainability criteria. Through it, we attempt to show the "applicability" of environmental education that is directed toward sustainability and the resolution of real and specific problems; bridging the gap between theory and practice and encouraging the development of sustainable competencies.

This work includes the proposal of a model for educational action that deals with the selection of socio-environmental actions that have to do with improving the sustainability of the faculty of education and of the campus, as well as their relationship with the surroundings, which are specified in Appendix 1. These themes respond to daily issues in student life, and they seek to adopt a certain type of personal and social behavior and the achievement of lifestyles that improve the environment [12]. In all of them, their relation to the excessive consumption for those aspects analyzed and their overall influence on environmental deterioration in other parts of the planet is to be established.

Of special relevance during the development process was the study of the multi-causal complexity of environmental problems, which involves three main tasks or procedures for its handling and resolution: (i) identify the intervening factors, distinguishing them from other relevant facts; (ii) analyze the network of connections among those factors; and (iii) evaluate their relative importance, that is determine the importance of each one as they occur in the situation studied. This requires social and scientific criticism and is complemented by a reflection on the process, where the data collected are analyzed and, if applicable, the activity plan (feedback) is reconsidered, and the development of a set of content agreed upon based on the information regarding the problems studied.

Recent studies on environmental education show the effectiveness of teaching approaches focused on the comprehensive view of an environmental problem and its possible solutions [51-54], for it enables the students to put forward their ideas, integrate their knowledge, make decisions and, all in all, use their competencies. Although there are many advantages to using this type of methodology, some authors also point out certain difficulties when it comes to implementing them. Thus, students can show initial reticence, stress and fear of not reaching the goals $[55,56]$ or show perspectives that are too limited when it comes to representing a complex problem [52]; in order to avoid this, we established different levels of complexity and potential viable solutions in the coordination meetings. 
Table 1. Stages in educational action.

\begin{tabular}{|c|c|c|}
\hline Stages & Main Activities in Each Stage & Competencies \\
\hline $\begin{array}{l}0 . \text { Selection of } \\
\text { socio-environmental problems }\end{array}$ & $\begin{array}{l}\text { Formulation of a problem: } \\
\text { - meaningful (with logical coherence, which awakens students' interest and activates their knowledge in a } \\
\text { new situation, which requires the learning of new knowledge and its transfer to a real context) } \\
\text { - } \quad \text { open (based on the complexity, with multiple solutions, which encourages debate and involves the use of } \\
\text { scientific data) }\end{array}$ & \\
\hline $\begin{array}{l}\text { 1. Formulation of the } \\
\text { problems that are the object of } \\
\text { the study }\end{array}$ & $\begin{array}{l}\text { - Identification and formulation of the problem based on students' previous knowledge } \\
\text { - Selection of meaningful content for students } \\
\text { - } \quad \text { Establishment of an initial work plan }\end{array}$ & $\begin{array}{l}\text { - Systems thinking competence } \\
\text { - Interpersonal competence }\end{array}$ \\
\hline $\begin{array}{l}\text { 2. Identification of causes } \\
\text { and consequences }\end{array}$ & $\begin{array}{l}\text { - Preparation of strategies to incorporate information that leads us to the identification of the causes and } \\
\text { consequences of the problem situation posed, taking into account the different points of view on the } \\
\text { conflicts and weighing the different factors that affect them (socials, cultural and economic) } \\
\text { - Information handling, selected to address the learning obstacles that appear during the research and that } \\
\text { come close to their level of knowledge }\end{array}$ & $\begin{array}{l}\text { - } \text { Systems thinking competence } \\
\text { - } \quad \text { Strategic competence } \\
\text { - }\end{array}$ \\
\hline $\begin{array}{l}\text { 3. Identification of the } \\
\text { conditions to change }\end{array}$ & $\begin{array}{l}\text { Definition of lines of action, establishing criteria for the selection and sequencing of proposed actions, } \\
\text { which give rise to questions, such as: what can be done through technology and science; what has been done } \\
\text { previously under similar conditions, and what was the result; who is responsible for providing solutions; to } \\
\text { what extent can citizens participate; what can we do? }\end{array}$ & $\begin{array}{ll}\text { - } & \text { Strategic competence } \\
\text { - } & \text { Anticipatory competence } \\
\text { - } & \text { Interpersonal competence }\end{array}$ \\
\hline $\begin{array}{l}\text { 4. Specification of the } \\
\text { difficulties and establishment } \\
\text { of priorities for action }\end{array}$ & $\begin{array}{l}\text { - Feasibility study of the proposals to be carried out (what are the blockades and obstacles we can come } \\
\text { across during the solution processes) to direct and change them if necessary, establishing different levels } \\
\text { of complexity to consider them feasible and prepare a calendar of actions } \\
\text { - Consideration of the lines of research aimed at looking for formulas for the resolution of conflicts, } \\
\text { mediation methods and new directions and participation mechanisms }\end{array}$ & $\begin{array}{ll}\text { - } & \text { Strategic competence } \\
\text { - } & \text { Interpersonal competence }\end{array}$ \\
\hline $\begin{array}{l}\text { 5. Carrying out of appropriate } \\
\text { and sustainable actions }\end{array}$ & Application of the concepts learned to real-life situations, fostering the ability to make sustainable decisions. & $\begin{array}{ll} & \text { Strategic competence } \\
\text { - } & \text { Normative competence } \\
\text { - } & \text { Interpersonal competence }\end{array}$ \\
\hline
\end{tabular}


The didactic model posed requires for its development a series of stages, both for on-campus and off-campus classes, where different activities are carried out as part of the learning sequence, that make it possible to apply the different aspects of the model [57]. The stages and their main activities are described in Table 1, where the sustainable competencies dealt with at all times are also described.

The initial stages of the experience are designed so that students may practice scientific and environmental literacy in order to achieve knowledge building, which involves the setting out and questioning of former ideas to analyze and resolve a real problem. During these early phases, the development of the competency of systems thinking and strategic and anticipatory competency through the global analysis of the theme that is the object of the study are particularly important.

It is not sufficient, however, to find solutions to specific environmental problems, for what is considered finding an adequate solution depends on one's own values, especially if we bear in mind that these problems could change in the future. Thus, the final stages of the experience are directed towards addressing the development of competencies that favor decision-making based on sustainability criteria and responsible behavior. For this reason, they are formulated to apply the contents to real-life situations, so as to foster skills for the use of knowledge, decision-making and acting in different contexts, both individually and collectively. This would encourage the application of the themes studied to real-life situations. These stages deal, above all, with the development of strategic competence, anticipatory competence and legislative competence through the process of identifying the conditions to be changed, the study of the different solutions and of the priorities upon which to act sustainably, on a local and global level.

It is also necessary to take into account that the environmental education model that we defend includes a positive approach to collective decision-making, respect for democracy, for different cultures, and the understanding of participation processes. Therefore, to develop this experience, the students were divided into small teams (4-5 students/group). Although environmental and social responsibility must be undertaken individually, they must develop into group-oriented actions. The aim is for students to act as a community that produces and mobilizes its own knowledge and is aware of and responsible for its learning, with the purpose of acting sustainably. Therefore, the development of interpersonal competency is encouraged during the entire process.

The educational experience began by providing each group with a text summary of the specific problem that was going to be "researched", the goals of the "research", a list of the activities to be carried out that dealt with a specific aspect of the problems involved and, if applicable, the prior considerations that need to be taken into account to carry them out. Therefore, the distribution of tasks was carried out as presented in Appendix 1. This meant that the groups worked exclusively on different indicators of sustainable management, with the final aim of drafting a report in order to then hold a debate and share them as a large group. Group work was periodically coordinated in established supervised modules and large group meetings. The role of the teachers was to guide the learning process of the students, monitoring the work of each group, coordinating information pooling, providing feedback on the learning process, presented in such a way that the difficulties (described above) that could arise during the application of this type of methodology could be solved. 


\section{Research Methods}

The research was designed with the purpose of evaluating the effect of an experimental educational model based on the development of sustainable competencies, as opposed to a traditional model based on an expository teaching methodology, within the scope of the Spanish Faculties of Education during academic year 2012-2013.

As per the view endorsed for the teaching model, a study of the students' initial situation was carried out, assessing their knowledge, attitudes and their intention of behavior toward the environment, not only as a starting point for their learning, but also as a reference to evaluate the change produced. Therefore, a quasi-experimental research was carried out [58], comparing the data before and after the teaching intervention. The distribution of the experimental and control groups was not performed in a random manner for institutional organization reasons. This type of research has been often used to evaluate the effect of educational interventions in the field of environmental education [59-61], although it presents certain limitations, such as possible cross-contamination when dealing with and comparing different groups from the same faculty, or the influence of other factors, such as student cultural and socio-economic characteristics, or the influence of the faculty.

\subsection{Research Participants}

The number of participants in the research totaled 300, from the Faculty of Education of the University of A Coruña and from the University of Granada, as can be seen in Table 2.

Table 2. Characteristics of the participants in the teaching experience.

\begin{tabular}{ccccccc}
\hline & \multirow{2}{*}{ No. } & Age & \multicolumn{2}{c}{ Origin } & \multicolumn{2}{c}{ Sex } \\
\cline { 3 - 6 } Experimental group & 196 & $\begin{array}{c}21.18(\mathrm{SD} 0.427) \\
(20-25)\end{array}$ & 72 & 124 & $139(71 \%)$ & $57(29 \%)$ \\
\hline Control group & 104 & $\begin{array}{c}21.32(\mathrm{SD}) 0.486) \\
(20-24)\end{array}$ & 25 & 79 & $76(73 \%)$ & $28(27 \%)$ \\
\hline
\end{tabular}

\subsection{Instruments}

Three instruments were used in the research process based on the study variable:

(1) A scale of environmental attitudes, previously built and validated [36], whose alpha coefficient (Cronbach's $\alpha$ ) for all items is very close to the unit (0.82), which shows the high feasibility of the scale.

(2) A previously validated questionnaire on basic knowledge regarding the environment and environmental problems [36].

(3) A scale for the intention of behavior with the purpose of analyzing the intention of behaving sustainably with regard to the protection and improvement of the environment (Appendix 2), designed and validated, which has produced the following data:

- Feasibility (Cronbach's $\alpha)=0.82$. 
- Variability (factorial analysis): following the Kaiser criteria [62], three factors have been extracted, with eigenvalues above 1.00: F1, whose eigenvalue $=12.35$ and percentage of variance $=51.7 ; \mathrm{F} 2$, whose eigenvalue $=2.89$ and percentage of variance $=11.4 ; \mathrm{F} 3$, whose eigenvalue $=1.78$ and percentage of variance $=8.36$.

- Derived stimulus configuration (Euclidean distance model): the items are grouped into several subsets, which correspond to different significant behaviors with regard to the intention of acting sustainably.

In this way, the characteristics of these instruments enable us to globally consider that the items in the questionnaire are adequate and are measuring a one-dimensional construct, whereby it makes sense to add the responses obtained in each of them in order to achieve a total score.

\subsection{The Research Process}

As far as the process and handling of the groups is concerned, it is necessary to point out that both groups (experimental and control) were handled at the same time and that the teaching experience lasted one whole academic year. The subjects from the control group, as opposed to the experimental group, followed an expository methodology. This methodology was based on "keynote" classes, where the teachers carried out the standardized content program for both faculties, for which the students had to memorize to be evaluated. This did not exclude afterschool outings and activities with the purpose of confirming the "reality" of what had been put forward in the classroom. At the same time, in the experimental model, the contents were taught following the experimental teaching model (described in the section above), aimed at achieving the ability to act sustainably. In both cases (Faculty of A Coruña and Granada), the subject was taught by the same teachers in the experimental and control group.

At the end of the experience, with the data collected, statistical analyses were performed to verify if the participants (teachers in training) who followed the experimental methodology significantly improved, in statistical terms, their environmental attitudes, their knowledge regarding the environment and their intention to carry out sustainable environmental actions, with respect to the subjects from the control group.

\section{Results and Analysis}

The data collected were analyzed with the statistical package SPSS (Statistical Package for Social Sciences), version 15.0, and Excel 2013.

The descriptive analysis of the data obtained in the pretest has a dual interest; on the one hand, it allowed us to verify the level of knowledge of the students at the beginning of the year, and on the other hand, it enabled us to contrast the change produced in the variables considered at the end of the year. Therefore, in the first case, we analyzed if there were statistically significant differences with regard to the personal variables and the dependent variables among the control and experimental subgroups (students from the University of Granada and students from the University of A Coruna). Having performed the corresponding tests, the data obtained indicated that there were no significant differences. To contrast possible differences among the initial knowledge of both groups, the Mann-Whitney test was performed on the percentages of correct answers, checking that there were no 
significant statistical differences among them (value $=47.09 ; p<0.84$ ); which was reinforced by means of a test on the equality of measures in independent samples (Student's $t$-test, where $t=0.19$; $p=0.00$ ). With regard to attitudes toward the environment, the data obtained from the pretest also show similar results for both groups; also, when analyzing the contrast between the control and experimental groups through a variance analysis (ANOVA), it was shown that there were no significant differences between the averages for the groups $(\mathrm{F}=8.43 ; p=0.00)$. With regard to the intention of performing sustainable behavior, the average score obtained by both groups is very similar: 35.84 out of 100 (standard deviation $=3.87$ ) for the control group and 35.846 (standard deviation $=3.91$ ) for the experimental group. We could therefore conclude that both groups studied (experimental group and control group) do not reveal statistically-significant differences in any of the personal and dependent variables considered in the pretest.

With the data collected from the posttest, the corresponding statistical analyses were performed to verify if the participants (teachers in training) who followed the experimental methodology significantly improved, in statistical terms, their environmental attitudes, their knowledge of the environment and their intention to carry out sustainable actions, compared to the subjects who belonged to the control group.

\subsection{Evolution of Knowledge}

The descriptive statistics regarding initial knowledge on the environment and environmental problems show that, mostly, the subjects from both groups (control and experimental) were not familiar with the concepts and conceptual structures related to the environment (such as SD, biodiversity or the greenhouse effect). Therefore, the initial scores obtained by both groups were quite low, though slightly higher than for the experimental group.

Regarding the importance (gravity) attributed to different environmental problems, the valuations are very similar for both groups, highlighting the tendency to give greater importance (to consider them more serious) to the problems in the subjects' immediate surroundings (attention to "that which is local", such as noise pollution, oil slicks), as opposed to other global problems (attention to "that which is global", such as climate change or food scarcity or waste).

After the experience, the analysis of the knowledge of the environment showed that the subjects from both groups achieved scores that were significantly higher than those obtained in the pretest; however, the experimental group scores were higher (average score $=8.87 ; \mathrm{D}=1.12$ ) than the control group scores (average score $=5.09 ; \mathrm{D}=1.94$ ). Furthermore, both the Mann-Whitney test on the percentages of correct answers by the members of each group (value of $U=6.038 ; p=0.001$ ), as well as the contrast of the average scores obtained $(t=12.463 ; p=0.001)$ showed that these differences were statistically significant. On the other hand, the contrast of averages for each group from the pretest and posttest also showed statistically-significant differences $(t=10.784 ; p=0.000)$; that is to say, although both groups have significantly increased their knowledge regarding the environment, the members of the experimental groups did so to a greater extent than those from the control group, as can be seen in Figure 1. 


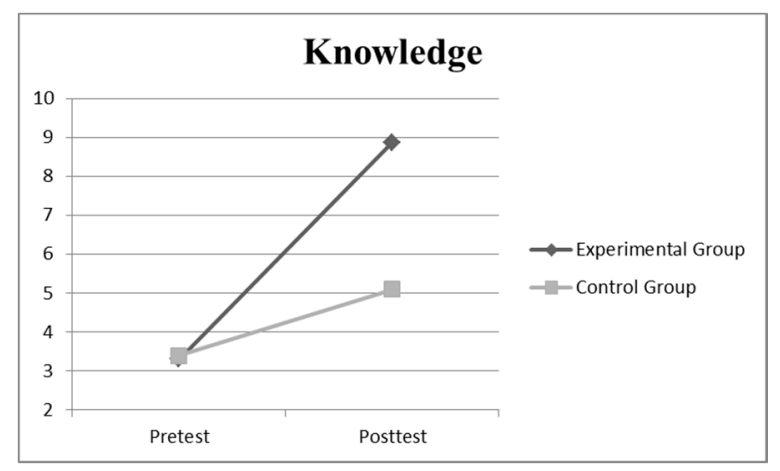

Figure 1. Evolution of knowledge of the environment and environmental problems.

The "a posteriori" tests (Tukey HSD and Scheffé test) performed on the control subgroups showed differences between both: while the students from the University of Granada significantly increased their knowledge (percentage of correct answers $=65.48 \%$ ), the students from the University of A Coruña did so to a lesser extent (percentage of correct answers $=59.72 \%$ ).

Regarding the valuation of the importance (gravity) of environmental problems after the teaching experience, we must highlight, on the one hand, the tendency of the experimental group members to give more importance to "global" problems (climate change, water pollution, desertification, etc.) and to show more concern for the deterioration of the environment that takes place in less developed countries due to our lifestyles (excessive use of resources and energy). The members of the control group, on the other hand, hardly changed the direction of their valuation with regard to the pretest.

\subsection{Evolution of Attitudes}

As far as attitudes are concerned, the contrast of the statistical results between the control and experimental groups from posttest data shows that there are significant differences between both groups. It is worth highlighting that the values obtained initially were quite high, which could be due to the high level of awareness that Spanish society has regarding the environment [63]. However, we cannot rule out that due to the type of instrument used, a Likert-type scale, the subjects have overrated this variable, because they see themselves as members of a unique project ("Hawthorne effect").

The values resulting from the Levene test for the equality of variances for the control $(\mathrm{F}=16.01$; significance $=0.00)$ and experimental $(F=27.63$; significance $=0.00)$ groups and from the Student's $t$-test for the equality of measurement for the control $(\mathrm{D}=21.03)$ and experimental $(\mathrm{D}=36.98)$ groups show that, in spite of the high level established in the pretest, there was an increase in the attitudinal level of the subjects from both groups, with the differences between both moments being statistically significant (see Figure 2). This increase in sustainable attitudes is greater in the experimental group; in fact, the contrast between the experimental and control group from the data obtained from the posttest shows that the differences between both groups are statistically significant. The evolution on those items related to the willingness to make personal sacrifices to favor sustainability (related to the over-exploitation of resources or to reducing the production of waste) and social participation stands out. 


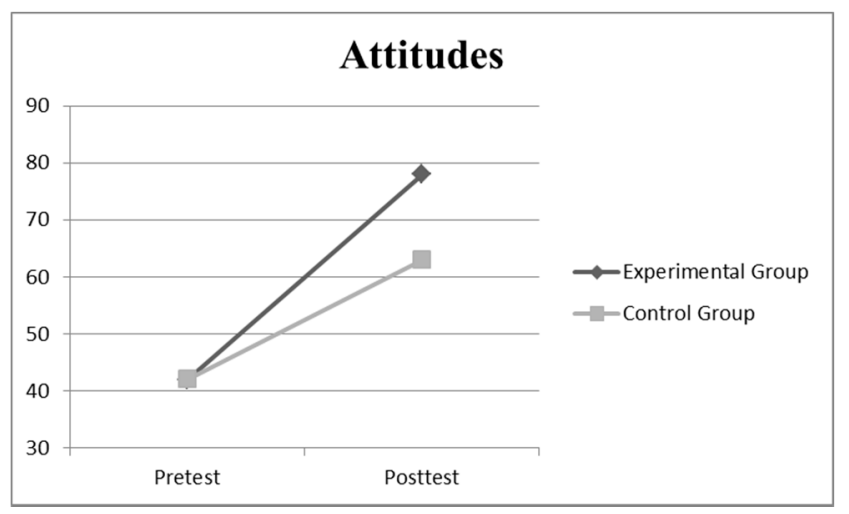

Figure 2. Evolution of attitudes towards the environment.

\subsection{Evolution of the Intention of Behavior}

With regard to the intention of behaving sustainably, with the data collected, we performed the descriptive statistics and the Student's $t$-test. The resulting values from the Levene test for equality of variances for the control $(F=0.61$; significance $=0.42)$ and experimental $(F=27.06$; significance $=0.00)$ groups and for the Student's $t$-test for the equality of measures for the control $(\mathrm{D}=0.84)$ and experimental $(\mathrm{D}=8.69)$ groups show that the greater differences between the experimental and the control group are those related to the intention of a pro-environmental behavior. As could be seen from the contrast between the data from the pretest $(\mathrm{D}=35.02)$ and posttest $(\mathrm{D}=44.87)$, only differences in the experimental group show a significant increase; however, the responses from the control group have not varied significantly with respect to the pretest (Figure 3). An increase in issues related to biodiversity, energy saving and responsible consumption stands out.

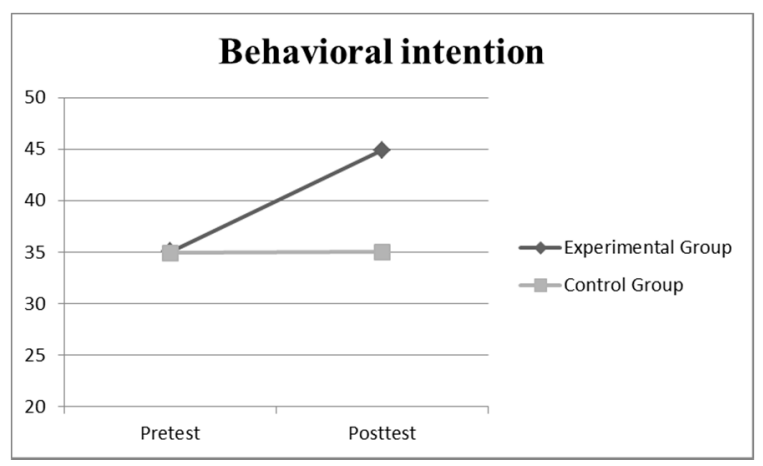

Figure 3. Evolution of the intention of behavior toward the environment.

Nowadays, the trend in educational models is towards experiential learning approaches focusing on the development of competencies and learning to learn skills [64], as shown in our research and in other studies. Teaching experiences based on the interdisciplinary and participative study of a real environmental problem can encourage the development of sustainable competencies and can be a powerful tool to enable university students to carry out their professional activities with the ethical and responsibility criteria of SD $[28,51]$. The stepwise process combined with additional principles allows building competencies, such as problem-solving, linking knowledge to action and collaborative work, 
while applying concepts and methods from the field of sustainability [51]. Thus, the implementation of this type of educational model in teaching training can especially boost SD [30].

These models aim to ensure that students mobilize, integrate and properly use different forms of knowledge in various real-life circumstances, and this achievement is closely linked to competency development [21]. To develop responsible citizens, the teaching and learning process should encourage students to master the described sustainable competencies (systems thinking competence, anticipatory competence, normative competence, strategic competence and interpersonal competence). Thus, learners will be able to combine knowledge, attitudes and behavior in order to take effective actions in different situations. The objective is not to prescribe certain behavioral patterns to pupils that could contribute to solving current environmental issues, but to educate future citizens, so that they can deal with present and future environmental problems in a critical, reflective and participative way. Therefore, the evaluation must be seen with regard to the development of pupils' will and ability to involve themselves in environmental issues and qualifying them to produce their own criteria for decision-making and the choice of actions; in this sense, action must be seen in a future perspective, where direction is not given beforehand [32], as evidenced by the results of this work.

The sustainable competencies developed in this experience encourage the improvement of knowledge that specifically trains for action (related to causes, consequences and action strategies). They also increase attitudes concerning the environment, pollution, biodiversity, resource scarcity, environmental impacts, participation and performance. Probably the greatest achievement is that they seem to promote sustainability actions in issues not related to the topics specifically worked on by each group.

Therefore, regarding concepts, we have seen that the subjects learn differentially more with the experimental educational model than with a traditional transfer type model, which is probably due to the use of a teaching model that deals with critical analysis and the development of competencies, such as systems thinking. Furthermore, the fact that it is based on the resolution of socio-environmental problems from a global perspective has made it possible to change the perception that students have of them. After the experience, the members of the experimental group considered "global" problems to be more important, while the members of the control group hardly changed their view with regard to the pretest. The research also revealed the development of pro-environmental attitudes, which increased in both cases, in spite of the fact that students' initial high attitudinal level left little margin for change. Here, it is worth highlighting that evolution was greater in the teaching experience that favored the development of competencies related to the so-called anticipation competencies and the legislative competencies.

When comparing both methodologies, the study's most significant differences are related to the development of sustainable actions. That is, only the intention of behavior increased among the aspiring teachers who participated in the experimental methodology based on the global understanding of problems and in the development of the different sustainable competencies. Therefore, the study seems to indicate that the integration of these skills into the sequence of activities can boost responsible behavior in aspiring teachers, as is revealed by the analysis carried out.

Regarding the development of the process, it is necessary to point out that students showed an initial reluctance toward the experimentation of a work method that is more active than the one they are used to, which demanded a greater intellectual and procedural effort than simple "note-taking". Although these variables did not appear as the object of our study and, therefore, were not quantified, we verified 
that during the debates, aspiring teachers had no trouble overcoming their initial reticence, and they even pointed out the motivating nature of the experience.

\section{Conclusions and Outlook}

The evaluation of this experimental teaching model seems to indicate that this is a highly effective resource for working from the point of view of environmental education focused on sustainability (at least at the university level) in so far as it favors the development of the knowledge, attitudes and pro-environmental intentions of behavior (aimed at sustainable) of aspiring teachers.

Therefore, the evaluation carried out for the teaching model shows significant implications for teaching practice. This formulation can foster behavior that is more respectful to sustainability, and it also includes a multiplying effect, due to the students' professional outlook (teachers in training). It is therefore very recommendable for teacher training actions related to environmental education to work on the development of sustainable competencies through the critical research of environmental problems and that they also deal with future scenarios or perspectives [32]. These problems must be close to the students and formulated through functional activities, thus searching for experiences that have nothing to do with traditional formulations "in the form of 'lectures' [65], where succession and continuity are carefully programmed in advance and imposed by the teachers".

We also wish to highlight that this approach for the development of environmental education aimed toward sustainability using the experimental methodology (active, participative and inclusive) requires a longer period of development than the one necessary for the expository methodology. Therefore, we consider that it must be included in the design for the teaching actions corresponding to the phase of off-campus classes, as is already established for the European higher education area [66], as we carried out in our experiment. Another limitation to this research that we wish to highlight is that we do not have data for the duration and effectiveness of our proposal, for it was not possible to follow up on it. We must also point out that it is not always easy for the intention of behavior to actually translate into real behavioral changes [13]. Therefore, it would be necessary to perform new studies that would make it possible to evaluate the duration of the results and the reality of the changes obtained, along with qualitative research that would make it possible to expand and delve into the conclusions. Therefore, this will be an objective of future works.

In summary, this research shows that an educational model based on the development of sustainable competencies through the resolution of socio-environmental problems seems to foster actions in favor of the environment in basic teacher training. Therefore, this approach can serve as a base for future proposals in this field, which could allow us to readdress education towards the training of citizens and communities that are not only knowledgeable and aware, but also capable of making responsible decisions and acting in a sustainable manner.

\section{Author Contributions}

These authors contributed equally to this work. 


\section{Appendix}

\section{Appendix 1. Group Distribution/Themes Developed.}

\section{Group A}

Identification of the learning center's environmental situation (1): water consumption;

waste water control

\section{Group B}

Identification of the learning center's environmental situation (2): energy consumption (analysis of electricity consumption and analysis of energy use for heating)

Group C

Identification of the learning center's environmental situation (3): testing of air pollution

(emissions and noise)

\section{Group D}

Identification of the learning center's environmental situation (4): production of waste

(solid urban waste and hazardous waste)

\section{Group E}

Identification of the learning center's environmental situation (5): paper (use and recycling)

\section{Group F}

Identification of the learning center's environmental situation (6): environmental information and awareness of the faculty's student body

Group G

Identification of the "environmental quality" of the faculties

Group H

Gathering of information from the different groups and drafting of a report with conclusions on the initial environmental evaluation

Major group

Preparation of a plan involving actions on a local level and their relationship with global socio-environmental problems

\section{Appendix 2. Behavioral Intention Assessment Questionnaire.}

Assess your own behavior on the following scale:

\begin{tabular}{llcll}
\hline & Never 1 & Sometimes 2 & Always 3 & \\
\hline 1 & At home, I always put different kinds of waste in different bags & 1 & 2 & 3 \\
\hline 2 & I go without certain things that make life easier to protect the environment & 1 & 2 & 3 \\
\hline 3 & I buy recycled paper, even if it's more expensive than ordinary paper & 1 & 2 & 3 \\
\hline 4 & I buy soft drinks in cans because they're easier to carry & 1 & 2 & 3 \\
\hline 5 & I use rechargeable batteries & 1 & 2 & 3 \\
\hline 6 & Every time I buy something, I think about the waste it produces & 1 & 2 & 3 \\
\hline 7 & I let the water run whilst I brush my teeth & 1 & 2 & 3 \\
\hline 8 & I use public transport to move around town & 1 & 2 & 3 \\
\hline
\end{tabular}




\begin{tabular}{lllll}
\hline 9 & I like to wear well-known brands of clothing, even when I dress casually & 1 & 2 & 3 \\
\hline 10 & I buy food and other products produced as locally as possible & 1 & 2 & 3 \\
\hline 11 & I like to have the central heating high, so I can be in short sleeves & 1 & 2 & 3 \\
\hline 12 & I take part in campaigns and demonstrations against attacks on the environment & 1 & 2 & 3 \\
\hline 13 & I usually buy disposable products & 1 & 2 & 3 \\
\hline 14 & I put bottles in bottle banks, even though I have to carry them there & 1 & 2 & 3 \\
\hline \multirow{2}{*}{15} & $\begin{array}{l}\text { I prefer to do my shopping in megastores or malls, because I can find } \\
\text { everything I want there }\end{array}$ & 1 & 2 & 3 \\
\hline 16 & I go on foot or by bicycle whenever I can & 1 & 2 & 3 \\
\hline 17 & I don't unplug electrical equipment when I'm not using it & 1 & 2 & 3 \\
\hline 18 & I try to keep up with fashion & 1 & 2 & 3 \\
\hline 19 & I leave the lights on when I go out of a room & 1 & 2 & 3 \\
\hline 20 & I prefer to buy things in shops that give part of their profits to needy countries & 1 & 2 & 3 \\
\hline
\end{tabular}

\section{Conflicts of Interest}

The authors declare no conflict of interest.

\section{References}

1. GEO-5. Fifth Global Environment Outlook: Summary for Policy Makers; United Nations Environment Programme: Nairobi, Kenya, 2012. Available online: http://www.unep.org/geo/geo5.asp (accessed on 1 December 2014).

2. United Nations Environment Programme. Measuring Progress: Environmental Goals \& Gaps; UNEP: Nairobi, Kenya, 2012. Available online: http:/www.unep.org/geo/pdfs/geo5/Measuring progress.pdf (accessed on 2 December 2014).

3. World Bank. Annual Report 2013; The World Bank: Washington, DC, USA, 2013. Available online: http://siteresources.worldbank.org/EXTANNREP2013/Resources/9304887-1377201212378/ 93058961377544753431/1_AnnualReport 2013_EN.pdf (accessed on 28 November 2014).

4. Worldwatch Institute. State of the World: Is Sustainability Still Possible? The Worldwatch Institute: Washington, DC, USA, 2013.

5. IPCC. Climate Change 2014: Impacts, Adaptation and Vulnerability; Intergovernmental Panel of Climate Change. Cambridge University Press: Cambridge, UK, 2014. Available online: http://www.ipcc.ch/pdf/assessmentreport/ar5/wg2/ ar5_wgII_spm_en.pdf (accessed on 14 February 2015).

6. Sachs, J. Common Wealth: Economics for A Crowded Planet; Penguin: London, UK, 2008.

7. Bardi, U. The Limits to Growth Revisited; Springer: London, UK, 2011.

8. Meadows, D.; Randers, J.; Meadows, D. Limits to Growth: The 30-Year Update; Green Publishing: Chelsea, UK, 2004.

9. Brundtland Report. World Commission on Environment and Development; Our Common Future; Oxford University Press: Oxford, UK, 1987; Volume 383.

10. General Assembly of United Nations. 55/2. United Nations Millennium Declaration, 2000. Available online: http://www.un.org/millennium/declaration/ares552e.htm (accessed on 20 February 2015). 
11. General Assembly of United Nations. 57/254. United Nations Decade of Education for Sustainable Development, 2002. Available online http:/www.un-documents.net/a57r254.htm (accessed on 20 February 2015).

12. Alvarez, P.; Vega, P. Actitudes ambientales y conductas sostenibles: Implicaciones para la Educación Ambiental [Environmental attitudes and sustainable behaviors: Implications for Environmental Education]. Rev. Psicodidact. 2009, 14, 245-260.

13. Gifford, R. Environmental psychology matters. Psychology 2014, 65, 541-585.

14. Jickling, B.; Wals, A.J. Probing Normative Research in Environmental Education: Ideas About Education and Ethics. In International Handbook of Research on Environmental Education; Stevenson, R.B., Brody, M., Dillon, J., Wals, A.E.J., Eds.; Routledge: New York, NY, USA, 2013; pp. 74-87.

15. Novo, M. La Educación Ambiental: Una genuina para el desarrollo sostenible [Environmental Education: A genuine education for sustainable development]. Rev. Educ. 2009, Special Issue, 219-237. (In Spanish)

16. Gresch, H.; Hasselhorn, M.; Bögeholz, S. Training in Decision-making Strategies: An approach to enhance students' competence to deal with socio-scientific issues. J. Sci. Educ. 2013, 35, 2587-2607.

17. Hodson, D. Time for action: Science education for an alternative future. J. Sci. Educ. 2003, 25, 645-670.

18. Mogensen, F.; Schnack, K. The action competence approach and the "new" discourses of education for sustainable development, competence and quality criteria. Environ. Educ. Res. 2010, $16,59-74$.

19. EU. The Bologna Declaration of 19 June 1999; Joint Declaration of the European Ministers of Education; European Union: Brussels, Belguim, 1999.

20. CRUE. Conference of Rectors from Spanish Universities; Informe Universidad: Madrid, Spain, 2000. Available online: http://www.crue.org/informeuniv2000.htm (accessed on 10 December 2014).

21. OECD. Definition and Selection Key Competencies: Executive Summary, 2005. Available online: http://www.oecd.org/pisa/35070367.pdf (accessed on 20 February 2015).

22. Stiefel, B.M. Competencias Básicas: Hacia un Nuevo Paradigma Educativo [Key Competencies: Towards a New Educational Paradigm]; Narcea: Madrid, Spain, 2008.

23. Bolívar, A. Deseñar e Avaliar por Competencias na Universidade; O EEES como reto. [Designing and evaluating competencies in university. The EHEA challenge]; Vicerreitoría de Formación e Innovación Educativa, Universidade de Vigo: Vigo, Spain, 2009.

24. Englund, T.; Öhman, J.; Östman, L. Deliberative communication for sustainability? A Habermas-inspired pluralistic approach. In Sustainability and Security within Liberal Societies; Gough, S., Stables, A., Eds.; Routledge: London, UK, 2008; pp. 29-48.

25. Ferreira, J. Unsettling orthodoxies: Education for the environmentl for sustainability. Environ. Educ. Res. 2009, 5, 607-620.

26. Stables, A.; Scot, W. The quest for holism in education for sustainable development. Environ. Educ. Res. 2002, 8, 53-60.

27. Wiek, A.; Withycombe, L.; Redman, C.L. Key competencies in sustainability: A reference framework for academic program development. Sustain. Sci. 2011, 6, 203-218. 
28. Barth, M.; Godemann J.; Rieckman M.; Stoltenberg, U. Developing key competences for sustainable development in higher education. Int. J. Sustain. High. Educ. 2007, 8, 416-430.

29. Dale, A.; Newman, L. Sustainable development, education and literacy. Int. J. Sustain. High. Educ. 2005, 6, 351-362.

30. Bertschy, F.; Künzli, C.; Lehmann, M. Teachers' Competencies for the Implementation of Educational Offers in the Field of Education for Sustainable Development. Sustainability 2013, 5, 5067-5080.

31. Kyburz-Graber, R. Socioecological Approaches to Environmental Education and Research: A Paradigmatic Response to Behavioural Change Orientations. In International Handbook of Research on Environmental Education; Stevenson, R.B., Brody, M., Dillon, J., Wals, A.E.J., Eds.; Routledge: New York, NY, USA, 2013; pp. 112-123.

32. Mogensen, F.; Mayer, M. Eco-Schools: Trends and Divergences; A Comparative Study on ECO-School Development Processes in 13 Countries; Austrian Federal Ministry of Education, Science and Culture: Viena, Austria, 2005.

33. Boyes, E.; Stanisstreet, M. Environmental Education for Behaviour Change: Which actions should be targeted? J. Sci. Educ. 2012, 34, 1591-1614.

34. Kincheloe, J.L. Knowledge and Critical Pedagogy: An Introduction; Springer: Dordrecht, The Netherlands; 2008.

35. Uzzell, D.; Rathzel, N. Transforming Environmental Psychology. J. Environ. Psychol. 2009, 29, 340-350.

36. Vega Marcote, P.; Álvarez Suárez, P. Environmental Education and consumption. A study didactic strategy to consume sustainably. In Proceedings of the the 6th World Environmental Education Congress (WEEC), Explore, Experience, Educate, Brisbane, Australia, 19-23 June 2011.

37. Crofton, F. Educating for sustainability: Opportunities in undergraduate engineering. J. Clean. Prod. 2000, 8, 397-405.

38. Porter, T.; Córdoba, J. Three views of systems theories and their implications for sustainability education. J. Manag. Educ. 2009, 33, 323-347.

39. De Haan, G. The BLK "21” programme in Germany: A "Gestaltungskompetenz"-based model for education for sustainable development. Environ. Educ. Res. 2006, 12, 19-32.

40. Withycombe, L.; Wiek, A. Anticipatory Competence as a Key Competence in Sustainability; Working Paper; Arizona State University: Tucson, AZ, USA, 2010.

41. Gibson, R. Sustainability assessment: Basic components of a practical approach. Impact Assess. Proj. Apprais. 2006, 24, 170-182.

42. Grunwald, A. Working towards sustainable development in the face of uncertainty and incomplete knowledge. J. Environ. Plan. Manag. 2007, 9, 245-262.

43. United Nations. Learning for the Future: Competences in Education for Sustainable Development; Economic Commission for Europe: Geneve, Switzerland, 2012 Available online: http://www.unece.org/fileadmin/DAM/env/esd/ESD_Publications/Competences_Publication.pdf (accessed on 20 February 2015).

44. UNESCO. The UN Decade of Education for Sustainable Development (2005-2014); Division for the Co-ordination of UN Priorities in Education: Paris, France, 2007. 
45. Aznar-Minguet, P.; Ull, M.A. La formación de competencias básicas para el desarrollo sostenible: El papel de la Universidad [The training of key competences for sustainable development: The role of the University]. Rev. Educ. 2009, Special Issue, 219-237. (In Spanish)

46. Berryman, T.; Sauvé, L. Languages and Discourses of Education, Environment, and Sustainable Development. In International Handbook of Research on Environmental Education; Stevenson, R.B., Brody, M., Dillon, J., Wals, A.E.J., Eds.; Routledge: New York, NY, USA, 2013; pp. 133-147.

47. Rideout, B.E. The effects of a brief environmental problems module on endorsement of the New Ecological Paradigm in college students. J. Environ. Educ. 2005, 37, 3-11.

48. Yavetz, B.; Goldman, D.; Pe'er, S. Environmental literacy of preservice teachers in Israel: A comparison between students at the onset and end of their studies. Environ. Educ. Res. 2009, $15,393-415$.

49. Tilbury, D. Higher Education for Sustainability: A Global Overview of Commitment and Progress. In Higher Education in the World 4. Higher Education's Commitment to Sustainability: from Understanding to Action; Palgrave: Barcelona, Spain, 2011.

50. Andersson, K.; Jagers, S.C.; Lindskog, A.; Martinsson, J. Learning for the Future? Effects of Education for Sustainable Development (ESD) on Teacher Education Students. Sustainability 2013, 5, 5135-5152.

51. Brundiers, K.; Wiek, A. Do We Teach What We Preach? An International Comparison of Problem- and Project-Based Learning Courses in Sustainability. Sustainability 2013, 5, 1725-1746.

52. Öhman, J.; Öhman, M. Participatory approach in practice: An analysis of student discussions about climate change. Environ. Educ. Res. 2013, 19, 324-341.

53. Rideout, B. The Effect of a Brief Environmental Problems Module on Endorsement of the New Ecological Paradigm in College Students. J. Environ. Educ. 2005, 37, 3-11.

54. Varela-Losada, M.; Pérez-Rodríguez, U.; Álvarez-Lires, J.; Álvarez-Lires, M. Desarrollo de competencias docentes a partir de metodologías participativas aplicadas a la Educación Ambiental [Developing teaching competences through participative methodologies on Environmental Education]. Formac. Univ. 2014, 7, 27-36.

55. Garmendia, M.; Fuentes, J.I.B.; Elosegi, K.Z.; Aranzábal, J.G. Proyecto de formación del profesorado universitario de Ciencias, Matemáticas y Tecnología, en las metodologías de Aprendizaje Basado en Problemas y Proyectos [Project of university teacher training of Science, Maths and Tecnology, in methodologies of Problem Based Learning and Projects]. Ensen. Cienc. 2014, 32, 113-129.

56. Shelton, J.B.; Smith, R.F. Problem-based learning in analytical science undergraduate teaching. Res. Sci. Technol. Educ. 1998, 16, 19-29.

57. Vega Marcote, P.; Álvarez Suárez, P. La Agenda 21 y la Huella Ecológica como instrumentos para lograr una Universidad Sostenible [Agenda 21 and ecological footprint as instruments for achieving a sustainable university]. Ensen. Cienc. 2011, 29, 207-220.

58. Shadish, W.R.; Cook, T.D.; Campbell, D.T. Experimental and Quasi-Experimental Designs for Generalized Causal Inference; Cengage Learning: Stamford, CT, USA, 2001. 
59. Dimopoulos, D.; Paraskevopoulos, S.; Pantis, J.D. The Cognitive and Attitudinal Effects of a Conservation Educational Module on Elementary School Students. J. Environ. Educ. 2008, 39, $7-61$.

60. Gottlieb, D.; Vigoda-Gadot, E.; Haim, A. Encouraging ecological behaviors among students by using the ecological footprint as an educational tool: A quasi-experimental design in a public high school in the city of Haifa. Environ. Educ. Res. 2013, 19, 844-863.

61. Johnson, B.; Manoli, C.C. The 2-MEV Scale in the United States: A Measure of Children's Environmental Attitudes Based on the Theory of Ecological Attitude. J. Environ. Educ. 2010, 42, 84-97.

62. Kaiser, H.F. An index of factorial simplicity. Psychometrika 1974, 39, 31-36.

63. Environmental Profile of Spain 2012. Available online: http://www.magrama.gob.es/es/ calidad-y-evaluacion-ambiental/publicaciones/PAE_2012_EN_tcm7-325754.pdf (accessed on 12 December 2014).

64. Chisholm, C.U.; Harris, M.S.G.; Northwood, D.O.; Johrendt, J.L. The Characterization of Work-Based Learning by Consideration of the Theories of Experiential Learning. Eur. J. Educ. 2009, 44, 319-337.

65. UNESCO. Trends, Needs and Priorities of Environmental Education Since the Tbilisi Conference: An Overview; Environmental Education; UNESCO: Paris, France, 1983; Volume 1.

66. EU. Recommendation of the European Parliament and of the Council of 18 June 2009 on the establishment of a European Quality Assurance Reference Framework for Vocational Education and Training, 2009. Available online: http://eur-lex.europa.eu/legal-content/EN/TXT/PDF/ ?uri=CELEX:32009H0708\%2801\%29\&from=EN (accessed on 20 February 2015).

(C) 2015 by the authors; licensee MDPI, Basel, Switzerland. This article is an open access article distributed under the terms and conditions of the Creative Commons Attribution license (http://creativecommons.org/licenses/by/4.0/). 